\title{
Etiology of Elderberry Cane Dieback Disease and Its Influence on Plant Growth and Flowering
}

\author{
Michele R. Warmund and Jeanne D. Mihail \\ Division of Plant Sciences, University of Missouri, Columbia, MO 65211
}

Additional index words. Heterophoma, Phoma, Sambucus nigra subsp. canadensis, fungal pathogen, vegetative growth

\begin{abstract}
Cane dieback and foliar necrosis caused by an unknown pathogen were observed in elderberry (Sambucus nigra subspecies) plantings in early Spring 2016. Studies were conducted to identify the causal organism and determine the effects of infection on vegetative growth and fruiting of selected elderberry cultivars under controlled conditions. A Heterophoma sp. was isolated from symptomatic 'Ranch' elderberry canes growing in a commercial planting in Missouri. In the subsequent 2017 experiments, all canes of 'Bob Gordon' plants inoculated with this Heterophoma isolate had reduced cane lengths, reduced numbers of leaves and leaflets, and failed to produce fruit. In a study using 'Scotia', none of the 32 inoculated canes had symptomatic tissue; but in a subsequent study, one of 16 inoculated canes had slight cane dieback, indicating a potential difference in cultivar susceptibility to the pathogen. In 2018 , seven elderberry cultivars ('Adams II', 'Bob Gordon', 'Marge', 'Ozark', 'Scotia', 'Wyldewood', and 'York') were inoculated with the same Heterophoma isolate, which was subsequently reisolated from the boundary of symptomatic and asymptomatic tissue, thereby confirming pathogenicity of the fungus. The fungus was tentatively identified as H. novae-verbascicola (Aveskamp, Gruyter \& Verkley) Q. Chen \& L. Cai based on analysis of genomic DNA from the internal transcribed space (ITS) region. Only two of 16 'Scotia' inoculated canes had cane dieback in 2018, whereas inoculated canes of all other cultivars developed symptoms. Cane and foliar growth of each inoculated cultivar was less than the associated noninoculated control at 14, 30, and 60 days after treatment (DAT). Among inoculated symptomatic plants, 'Marge' canes produced more vegetative growth than all other cultivars, and 'Adams II', 'Ozark', and 'York' canes generally produced the fewest number of leaves and leaflets at 60 DAT. Flowering was observed on canes of noninoculated control plants, but not on inoculated symptomatic canes by 60 DAT. Thus, the newly reported cane dieback disease of elderberry, caused by Heterophoma sp., adversely affected plant growth and fruiting of Sambucus nigra subspecies. However, 'Scotia' elderberry plants were less susceptible to the fungal infection than other cultivars, indicating that it may be possible to use 'Scotia' to develop new elderberry cultivars with improved resistance to infection by Heterophoma.
\end{abstract}

Elderberry (Sambucus spp.) is a specialty crop grown primarily in North America and Europe for niche markets (Charlebois et al., 2010; Mohebalian et al., 2012). American elderberry [Sambucus nigra L. ssp. canadensis (L.) Bolli] plants thrive in moist, welldrained soils and are multistemmed shrubs with odd-pinnately compound leaves. Flowering occurs in early summer and fruitbearing umbels are generally harvested in late July and August (Finn et al., 2008; Zomlefer, 1994). For commercial plantings, some fruit can be harvested the year of planting. Elderberry fruit yield for mature (5-year-old) plants at a $1.2 \times 3.7 \mathrm{~m}$ spacing typically averages $4580 \mathrm{~kg} \cdot \mathrm{ha}^{-1}$, with replant-

Received for publication 16 July 2019. Accepted for publication 16 July 2019 .

This work was supported by a contribution from the Missouri Agricultural Station Project 322.

M.R.W. is the corresponding author. E-mail: warmundm@missouri.edu.
1978). Cytospora, Diplodia, Nectria, Neonectria, and Sphaeropsis spp. are fungi that have been associated with cankers and mortality of the distal end of elderberry canes (Charlebois et al., 2010). The incidence of cane dieback and foliar necrosis symptoms in early spring has been consistently observed in commercial elderberry plantings and potted plants grown in nurseries (Fig. 1) (M.R Warmund, unpublished data).

Because little research has been conducted on pathogens of elderberry or their impact on host plants, studies were conducted to 1) identify the pathogen causally associated with cane dieback in Missouri; and 2) determine the effect of dieback on vegetative growth and flowering of selected elderberry cultivars inoculated with the fungal isolate recovered from symptomatic plants.

\section{Materials and Methods}

Fungal isolation and identification. Necrotic tissue at the distal portion of canes on five 'Ranch' elderberry plants was collected from a commercial planting near New Bloomfield, MO on 13 May 2016. Dieback was observed on multiple canes with leaf and petiole necrosis on affected canes. However, symptoms were not observed on entire plants. Immediately after tissue collection, symptomatic petiole and stem tissue was surfacedisinfected with $70 \%$ ethanol for $30 \mathrm{~s}$ followed by three rinses in sterile distilled water. Next, tissue was placed on standard culture media, $25 \%$ strength potato dextrose agar (PDA, Difco, Sparks, MD) and 2\% water agar (Technical agar; Difco, Sparks, MD) to permit the emergence of putative pathogenic organisms. After several days, subcultures of candidate pathogens were made to obtain axenic cultures. All working cultures were maintained on a $50 \%$ strength PDA at room temperature $\left(20\right.$ to $23{ }^{\circ} \mathrm{C}$ ) under fluorescent light with a 14-h photoperiod.

The most consistently recovered fungus had morphological features consistent with after establishment (Godsey, 2012).

'Adams II', 'Bob Gordon', 'Ozark', 'Scotia', 'Wyldewood', and 'York' are American elderberry cultivars commonly grown in the United States (Finn et al., 2008; Warmund et al., 2016). 'Marge', a productive European elderberry cultivar [Sambucus nigra L. ssp. nigra (L.)], is becoming popular, with several new plantings in the eastern United States (Thomas et al., 2015b). To date, these cultivars, as well as others grown in North America and Europe, were selected from wild germplasm for improved plant vigor, inflorescence position, high fruit yield, ripening date, and pest resistance (Byers and Thomas, 2011; Byers et al., 2010; Charlebois et al., 2010).

Like other perennial fruit crops, pathogens may become visually evident and problematic as elderberry plantings mature (Warmund et al., 2019). Fungal pathogens causing cankers, leaf spots, blights, and root rots on elderberry have been reported by others (Charlebois et al., 2010; Pirone et al.,

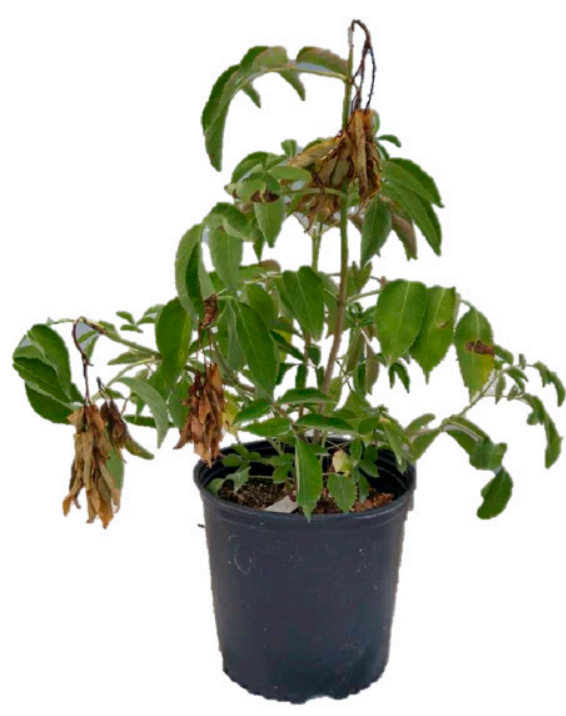

Fig. 1. 'Bob Gordon' elderberry plant exhibiting symptoms of cane dieback disease. 
Phoma as described in the Results. The isolate used in subsequent experiments was further identified to species based on genomic DNA as described by Cottrill et al. (2016). Briefly, genomic DNA was extracted with the Easy-DNA kit (Invitrogen Corp., Carlsbad, CA) following the manufacturer's instructions. Extracted DNA was amplified through PCR (polymerase chain reaction). Ribosomal DNA (rDNA) amplification of the ITS region was accomplished with the ITS1 primer. Amplification of the ITS2 region used the primer set ITS1f (CTTGGTCATTTAGAGGAAGTAA) and ITS4 (TCCTCCGCTTATTGATATGC) following the protocols of Gardes and Bruns (1993) and Henrion et al. (1992). Specifically, each PRC reaction was $50 \mu \mathrm{L}$ in total volume, including a $10 \mu \mathrm{L}$ buffer (MyTaq red reaction buffer; Bioline, Taunton, MA), 200 $\mathrm{nM}$ of each primer, $0.2 \mu \mathrm{L}$ of Taq polymerase (Bioline, Tauton, MA), and $50 \mathrm{ng}$ of DNA sample. Thermal cycling conditions were as follows: denaturation at $94{ }^{\circ} \mathrm{C}$ for $1 \mathrm{~min} ; 33$ cycles of $94{ }^{\circ} \mathrm{C}$ for $30 \mathrm{~s}, 65^{\circ} \mathrm{C}$ for $1 \mathrm{~min}$, and $72{ }^{\circ} \mathrm{C}$ for $1 \mathrm{~min}$; and a final extension step at $72^{\circ} \mathrm{C}$ for $2 \mathrm{~min}$. Following amplification, DNA was purified using the QIAquick PCR Purification Kit (Qiagen, Valencia, CA) following the manufacturer's instructions. Purified, amplified DNA samples were then submitted to the University of Missouri DNA sequencing facility. A consensus sequence for each isolate based on the two primer sets was compared with sequences stored in GenBank, using the Basic Local Alignment Search Tool (BLAST) algorithm (Altschul et al., 1990).

Pathogenicity experiments in 2017. For these experiments, 'Bob Gordon' and 'Scotia' plants were obtained from a commercial nursery (Botany Shop, Joplin, MO) on 14 Feb. 2017 and were transplanted into $8.5 \mathrm{~L}$ polyethylene containers using Pro-Mix BX (Premier Tech Horticulture, Quakertown, PA). Potted plants were placed in a greenhouse maintained at a $22{ }^{\circ} \mathrm{C}$ day/ $18{ }^{\circ} \mathrm{C}$ night cycle under natural light and were pruned to a $30 \mathrm{~cm}$ height above the medium surface, leaving four canes per pot. On 21 Feb. 2017, $50 \mathrm{~g}$ of $15 \mathrm{~N}-9 \mathrm{P}-12 \mathrm{~K}$ controlled-release fertilizer (Osmocote; Scotts Company, Marysville, $\mathrm{OH}$ ) was applied to the medium surface of the potted elderberry plants.

On 10 Mar. 2017, four canes on each of eight 'Bob Gordon' plants were prepared for inoculation by piercing the stem tips 12 times using dressmaker's pins to a maximum depth of $1 \mathrm{~mm}$ (Baker et al., 1995; Parker and Ramsdell, 1977; Weingartner and Klos, 1975). Injured stems were then inoculated with $5.8 \times 10^{6} \mathrm{H}$. novae-verbascicola con$\mathrm{idia} / \mathrm{mL}$ suspended in $0.1 \%$ dioctyl sulfosuccinate (DSS; Sigma Co., St. Louis, MO), using the method of Reynolds and Barton (2014). The fungal isolate was derived from the original isolate identified, as described in the prior section. An aerosol pressurized sprayer (Preval, Coal City, IL), delivering $20 \mathrm{~mL}$ of inoculum solution, was used to treat individual canes. Four canes on each of eight 'Bob Gordon' plants were also sprayed with $0.1 \%$ DSS to serve as controls. Immediately after inoculation, treated canes were sealed in $10 \times 24 \mathrm{~cm}$ clear cellophane bags (MSPCI, Irving, TX) for incubation. Plants were then placed in a growth chamber in a completely randomized design at $85 \%$ relative humidity, a $22{ }^{\circ} \mathrm{C}$ day $/ 18{ }^{\circ} \mathrm{C}$ night cycle, and a $14-\mathrm{h}$ photoperiod with light intensity of 500 $\mu \mathrm{mol} \cdot \mathrm{m}^{-2} \cdot \mathrm{s}^{-1}$ at canopy level. Bags were removed from plant canes after $12 \mathrm{~d}$. At this time, symptomatic tissue was treated with $70 \%$ ethanol for $30 \mathrm{~s}$ followed by three rinses in sterile, distilled water to recover the putative pathogen. Tissue segments $(\approx 2 \times$ $2 \mathrm{~mm}$ ) excised from the border between symptomatic and asymptomatic tissue were then placed on a $50 \%$ strength PDA for incubation at room temperature under fluorescent light with a 14-h photoperiod. Asymptomatic tissue, similarly sampled, was also placed on PDA media. Typical colonies were subcultured, and the identity of all putative Heterophoma isolates was confirmed morphologically.

Cane lengths, and leaf and leaflet numbers were recorded one day before inoculation and 14, 30, 60, 90, 120, and 150 DAT. When growth from axillary buds occurred on canes, their lengths, and leaf and leaflet numbers were also recorded. Plant growth was assessed as cane length and leaf and leaflet numbers on an evaluation day, less the initial value for that plant (measured one day before treatment). Plant growth data were analyzed using the TTEST procedure of SAS software (SAS 9.4; SAS Institute Inc., Cary, NC). To test mean differences, a pooled test was used when variances were equal and the Satterthwaite test was used when variances were unequal $(P<0.05)$

On 15 May 2017, eight 'Scotia' plants growing in the greenhouse were inoculated and placed in a growth chamber (as described in the previous two paragraphs). Four canes/ plant were sprayed with $6.8 \times 10^{5}$ conidia $/ \mathrm{mL}$ of the same Heterophoma novae-verbascicola isolate suspended in $0.1 \%$ DSS, and eight control plants were also treated with $0.1 \%$ DSS. After $60 \mathrm{~d}$ in the growth chamber, this experiment was ended due to the absence of visible disease symptoms.

Another experiment was conducted on 'Bob Gordon' and 'Scotia' plants on 4 June 2017. In this experiment, two canes were inoculated with $1.6 \times 10^{7}$ conidia $/ \mathrm{mL}$ of the same Heterophoma sp. isolate, and the other two canes on the same plant served as controls. After treatment, plants were placed in a room at $21{ }^{\circ} \mathrm{C}$ with a 12 -h photoperiod using florescent lighting for $12 \mathrm{~d}$. Bags were then removed, and asymptomatic tissue was sampled from noninoculated canes. Symptomatic tissue from inoculated canes was also sampled for reisolation of the pathogen at this time, and the identity of isolates was confirmed morphologically, as previously described. Plants were then moved to a greenhouse maintained at $28{ }^{\circ} \mathrm{C}$ day/23 ${ }^{\circ} \mathrm{C}$ night with natural lighting. Cane lengths, and leaf and leaflet numbers were recorded the day before plant inoculation and at 14, 30, and 60 DAT. Plant growth data recorded from 'Bob Gordon' plants were analyzed as previously described. Because only one inoculated cane exhibited dieback symptoms, growth data for inoculated asymptomatic and noninoculated 'Scotia' plants at 60 DAT were analyzed using the TTEST procedure of SAS software with mean differences tested as previously described.

Pathogenicity experiment in 2018. 'York' and 'Marge' elderberry propagules were obtained from a commercial nursery (Indiana Berry Comp., Plymouth, IN). 'Adams II', 'Bob Gordon', 'Scotia', 'Ozark', and 'Wyldewood' cuttings were pruned from plants growing at the Horticulture and Agroforestry Research Center (New Franklin, MO). Cuttings $(1 \mathrm{~cm}$ in diameter) were pruned to six buds, and the proximal portion of the cane was dipped in $0.3 \%$ indole-3-butyric acid (Hormodin 2; OHP, Inc., Mainland, PA) before placing propagules in $40 \times 40 \times 15$ $\mathrm{cm}$ (depth) polyethylene flats (Stuewe \& Sons, Tangent, OR) filled with potting medium (ProMix BX; Premier Tech Horticulture, Québec, Canada). Flats were then placed in a greenhouse maintained at $21^{\circ} \mathrm{C}$ under natural lighting. After rooting occurred, cuttings were transplanted into $8.5 \mathrm{~L}$ polyethylene containers using the same potting medium. Sixteen plants per cultivar, each with four uniform canes, were selected for this experiment. For each cultivar, two canes on each of eight plants were inoculated with $7.5 \times 10^{6}$ conidia $/ \mathrm{mL}$ of the same H. novae-verbascicola isolate on 14 May 2018, using the puncture technique previously described. For controls, two canes on eight plants were also punctured and treated with $0.1 \%$ DSS. Canes were bagged immediately after treatment, and plants were incubated at $21{ }^{\circ} \mathrm{C}$ for $12 \mathrm{~d}$. Bags were removed from canes, tissue was sampled for reisolation of the pathogen, and the identity of isolates was confirmed morphologically, as described in the first experiment. Plants were then moved to the greenhouse maintained at $28{ }^{\circ} \mathrm{C}$ day $/ 23{ }^{\circ} \mathrm{C}$ night. Cane lengths, and leaf and leaflet numbers were recorded the day before plant inoculation and at 14,30, and 60 DAT. Data were analyzed as a split plot in time, as described by Littell et al. (1998) and were analyzed as a $2 \times 2 \times 6$ factorial arrangement of treatments (cultivar, inoculation, and time), using the PROC GLIMMIX statement of SAS software. The main plot included the effects of cultivar, inoculation, and their interaction. The subplot was the effect of time and all possible interactions of time and all main plot effects. Means were separated by Fisher's protected least significant difference test $(P<0.05)$. Growth data for inoculated asymptomatic and noninoculated 'Scotia' plants were also analyzed using the TTEST procedure of SAS software with mean differences tested as described above.

\section{Results}

Identification of pathogen. Following the initial isolation of the putative pathogenic 
fungus in axenic culture, scattered, globose pycnidia and hyaline single-cell conidia with two prominent guttules (i.e., oil-like drops) typical of fungi in the genus Phoma were observed (Chen et al., 2017). However, because Phoma is considered a polyphyletic genus, which has been divided into a cluster of related genera, including Heterophoma, species identification was based on DNA sequence analysis. Using sequences from the ITS region, the putative pathogenic fungus was tentatively identified as $\mathrm{H}$. novae-verbascicola (Aveskamp, Gruyter \& Verkley) Q. Chen \& L. Cai, with a $97 \%$ coverage match to GenBank sequences. The same analysis also yielded a $96 \%$ coverage match with Phoma herbarum Westend., which is now recognized as a highly polyphyletic species from which many genera and species have been separated (Chen et al., 2017). The $P$. herbarum sequence with a $96 \%$ match to the elderberry isolate was deposited in GenBank before the separation of $P$. herbarum into multiple taxa by Chen et al. (2017). Because $H$. novae-verbascicola represents a genetically more restricted component of $P$. herbarum and the elderberry isolate matched $H$. novae-verbascicola at the $97 \%$ level, this binomial was tentatively assigned to the elderberry isolate.

Pathogenicity experiment in 2017. Tissue necrosis and dieback was observed on inoculated 'Bob Gordon' canes at 14 DAT. Heterophoma was recovered from all plants expressing dieback symptoms, but not from asymptomatic tissue from noninoculated controls. Mean cane length at this time decreased by $1.3 \mathrm{~cm}$, whereas that of noninoculated plants increased by $3 \mathrm{~cm}$ (Fig. 2). Shoot growth from some axillary buds on the inoculated elderberry canes occurred by 30 DAT and continued throughout the growing season, but lengths of inoculated canes were less than that of noninoculated controls at all dates of data collection. By 150 DAT, cane length of inoculated 'Bob Gordon' plants was reduced by $65 \%$ when compared with the controls. Similarly, foliar necrosis was observed on inoculated 'Bob Gordon' plants, whereas visible symptoms of infection were absent on noninoculated plants at 14 DAT. Thereafter, foliar growth increased on all plants, but leaf and leaflet numbers of inoculated canes were less than those of noninoculated controls (Figs. 3 and 4). By the end of the growing season, inoculated canes never flowered or produced fruit. However, each noninoculated cane produced an inflorescence and developed fruit, averaging $29 \mathrm{~g} /$ umbel. Unlike 'Bob Gordon' plants, visible symptoms of infection were not observed at any time on 'Scotia' plants inoculated on 15 May 2017 (data not shown), and all plants produced fruit, averaging $14.9 \mathrm{~g} / \mathrm{umbel}$ by 150 DAT.

When elderberry plants were inoculated on 4 June 2017, dieback and foliar necrosis were observed on inoculated 'Bob Gordon' canes by 12 DAT. Furthermore, H. novaeverbascicola was reisolated from symptomatic tissue on all inoculated canes sampled at

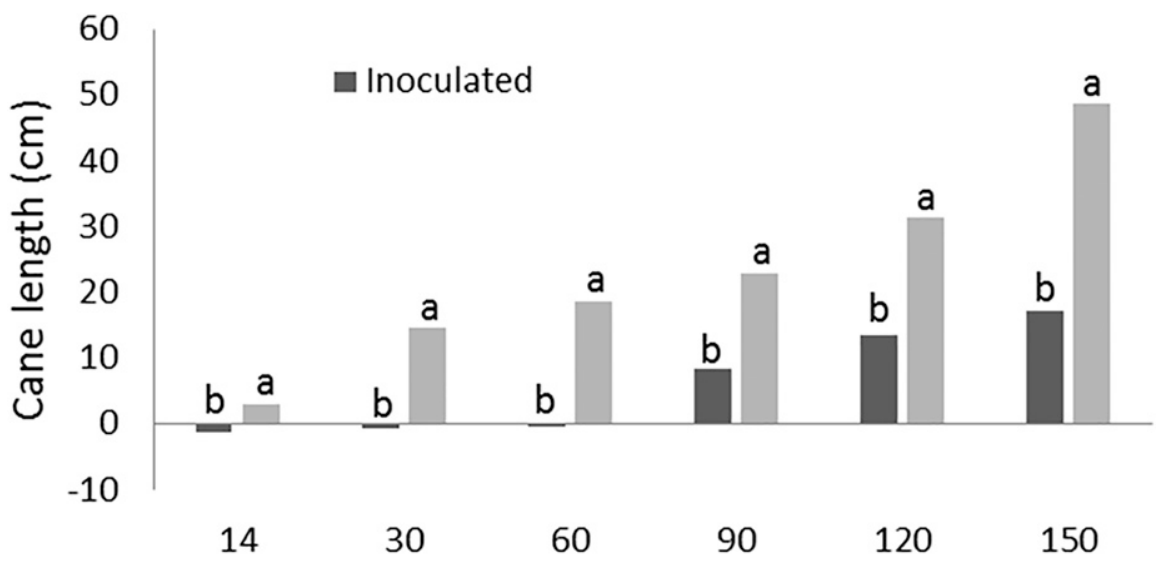

\section{Days after Inoculation}

Fig. 2. Change in cane length of 'Bob Gordon' elderberry plants inoculated with Heterophoma novaeverbascicola or noninoculated on 10 Mar. 2017. Means were calculated from cane lengths recorded one day before treatment to 14, 30,60, 90, 120, and $150 \mathrm{~d}$ after inoculation. Negative values indicate cane dieback following inoculation. Each value represents the mean of eight replications of each treatment. Mean separation by a pooled test when variances were equal or by the Satterthwaite test when variances were unequal. At each evaluation time, means with different letters were significantly different at $P \leq 0.05$.

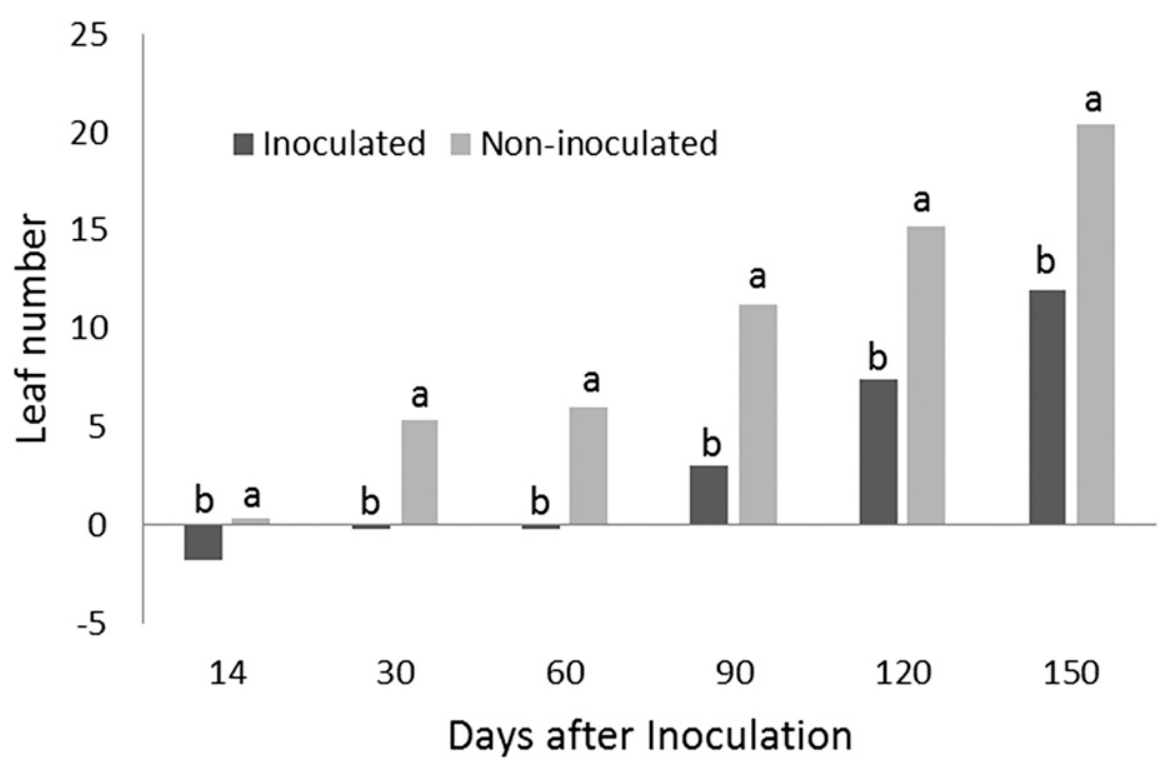

Fig. 3. Change in leaf number of 'Bob Gordon' elderberry plants inoculated with Heterophoma novaeverbascicola or noninoculated on 10 Mar. 2017. Means were calculated from leaf numbers recorded one day before treatment to $14,30,60,90,120$, and $150 \mathrm{~d}$ after inoculation. Negative values indicate leaf mortality following inoculation. Each value represents the mean of eight replications of each treatment. Mean separation by a pooled test when variances were equal or by the Satterthwaite test when variances were unequal. At each evaluation time, means with different letters were significantly different at $P \leq 0.05$.

12 DAT, whereas this fungus was not recovered from asymptomatic tissue from noninoculated canes. Again, the identity of all isolates recovered was confirmed morphologically by microscopic examination. At each date, cane length and leaf and leaflet numbers of inoculated 'Bob Gordon' plants were less than noninoculated controls (Table 1). Only noninoculated canes produced fruit, averaging $34 \mathrm{~g} / \mathrm{um}$ bel. In contrast, only one of the 16 'Scotia' canes inoculated with Heterophoma sp. exhibited a $1.2 \mathrm{~cm}$-long necrotic lesion and two dead leaves by 14 DAT. By 60 DAT, inoculated asymptomatic canes on 'Scotia' plants increased in stem length by $53 \mathrm{~cm}$, and leaf and leaflet numbers increased by 16 and 104, respectively. The increases in cane lengths and leaf and leaflet numbers on inoculated asymptomatic 'Scotia' canes were similar to those on noninoculated canes on the same cultivar at 60 DAT $(P=0.21,0.24,0.34$, respectively). With the exception of the one cane 
exhibiting symptoms of infection, at least one cane on all other 'Scotia' plants produced fruit by the end of the growing season, averaging $15.2 \mathrm{~g} / \mathrm{umbel}$.

Pathogenicity experiment and cultivar comparison in 2018. All cultivars inoculated with Heterophoma sp. had cane dieback by 14 DAT (Table 2), using an inoculum level (7.5 $\times$ $10^{6}$ conida $/ \mathrm{mL}$ ) similar to that used in the first pathogenicity test conducted in $2017\left(5.8 \times 10^{6}\right.$ conida $/ \mathrm{mL}$ ). However, these symptoms occurred on only two inoculated 'Scotia' plants. When tissue was sampled from inoculated canes and reisolated cultures were examined, H. novae-verbascicola was recovered from all the symptomatic specimens, and the identity of reisolated fungi was confirmed by microscopic examination of morphological features. The fungus was not recovered from asymptomatic tissue of noninoculated controls. At all dates, inoculated plants of all cultivars had less cane growth than the noninoculated controls of the same cultivar. For inoculated plants, 'York', 'Bob Gordon', and 'Wyldewood' had more cane dieback than all other cultivars at 14 DAT. By 30 DAT, new growth occurred from axillary buds, with inoculated 'Marge', 'Bob Gordon', and 'Wyldewood' canes producing more new growth than inoculated 'Adams II', 'Ozark', and 'York' canes. At 60 DAT, inoculated 'Marge' canes grew more than those of all other cultivars, except for 'Scotia' and 'Marge' controls. In contrast, inoculated 'Scotia' (symptomatic), 'Ozark', and 'Bob Gordon' had the least cane growth. The increase in cane length of inoculated asymptomatic canes on 'Scotia' plants was similar to that of noninoculated plants of the same cultivar at all evaluation dates (data not shown).

Inoculated elderberry plants from which $H$. novae-verbascicola was reisolated averaged 2 to 7 necrotic leaves at 14 DAT (Table 2). 'Bob Gordon' had greater leaf mortality than all inoculated cultivars except 'York'. By 30 DAT, most inoculated canes produced at least one new leaf, whereas noninoculated control canes averaged 7 to 13 new leaves. Substantial foliar growth occurred thereafter. By 60 DAT, inoculated symptomatic 'Scotia' and 'Marge' canes produced an equal number or more new leaves than noninoculated 'Adams II', 'Ozark', and 'Wyldewood' canes. Inoculated 'Adams II' and 'York' canes produced the fewest number of leaves. The increase in leaf number on asymptomatic inoculated canes of 'Scotia' plants was similar to the increase in leaf number on noninoculated plants of the same cultivar at all evaluation dates (data not shown).

Leaflet mortality varied among inoculated cultivars (Table 2). Inoculated 'York', 'Bob Gordon', and 'Wyldewood' canes had a greater number of necrotic leaflets than other inoculated cultivars at 14 DAT. Cultivars also differed in leaflet growth at 30 DAT. Inoculated 'Marge' and 'Wyldewood' canes averaged 16 new leaflets, whereas other inoculated cultivars (except 'Ozark' and 'Bob Gordon') had half as many new leaflets. Many new leaflets grew

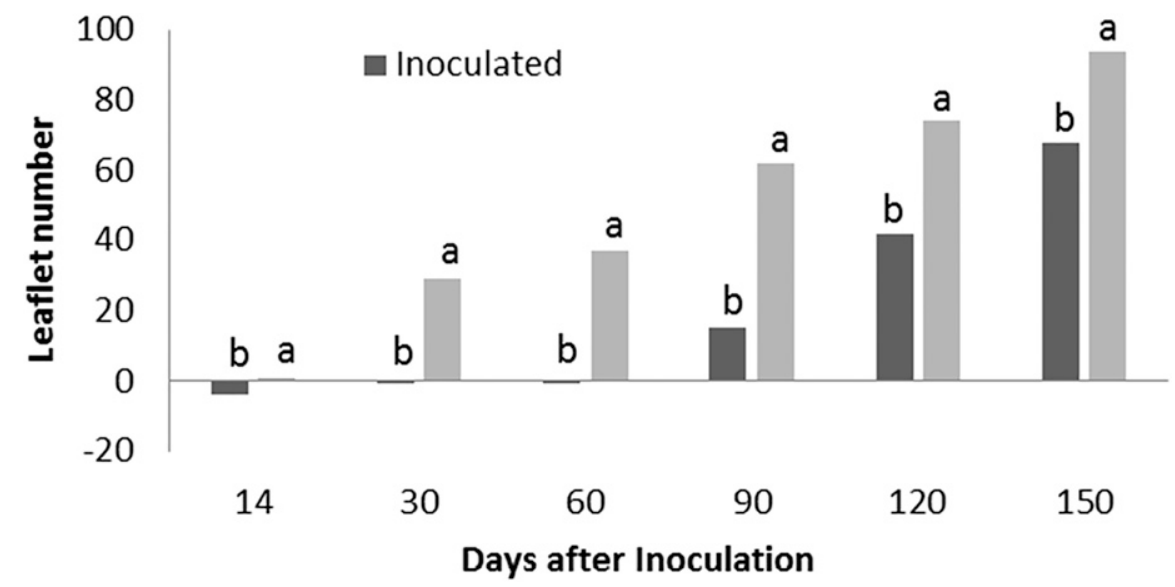

Fig. 4. Change in leaflet number of 'Bob Gordon' elderberry plants inoculated with Heterophoma novaeverbascicola or noninoculated on 10 Mar. 2017. Means were calculated from leaflet numbers recorded one day before treatment to $14,30,60,90,120$, and $150 \mathrm{~d}$ after inoculation. Negative values indicate leaflet mortality following inoculation. Each value represents the mean of eight replications of each treatment. Mean separation by a pooled test when variances were equal or by a Satterthwaite test when variances were unequal. At each evaluation date, means were significantly different at $P \leq 0.05$. thereafter, but inoculated canes always had fewer new leaflets than noninoculated ones. Among the inoculated cultivars, 'Marge' canes produced the most new leaflets and 'Adams II', 'Ozark', and 'York' had the fewest leaflets by 60 DAT. Flowering occurred on canes of noninoculated plants, but it was not observed on any of the H. novaeverbascicola-inoculated canes by 60 DAT. The increase in leaflet number on inoculated asymptomatic canes of 'Scotia' plants was similar to the increase in leaflet number on noninoculated plants of the same cultivar at all evaluation dates (data not shown).

\section{Discussion}

This article is the first report of H. novaeverbascicola infecting elderberry and causing cane dieback, reduced foliar growth, and suppression of flowering and fruit production. Walter et al. (2016) reported a fruit wilt of European elder caused by several species of fungi in the Phoma complex. Genetically diverse isolates caused similar fruit symptoms across multiple locations in Austria. However, $H$. novae-verbascicola has not been previously associated with any Sambucus species - although there are two reports that this fungus (syn. P. novae-verbascicola) can cause leaf spots and contaminate seeds of black mullein (Verbascum nigrum L.) (Bertetti et al., 2016; Garibaldi et al., 2013). Confirmation of the identity of the fungal strain used in this work as H. novae-verbascicola will require the inclusion of this strain in a broader phylogenetic evaluation of North American Phoma species.

In our study, elderberry cultivars of both Sambucus subspecies inoculated with our $H$. novae-verbascicola isolate expressed visual symptoms. Because floral development occurs at the distal end of a current season's growth of American elderberry canes and in the same region of older canes of European cultivars, floral meristems were likely injured by fungal infection after inoculation, resulting in the absence of fruit on affected tissue. Noninoculated canes, occurring on the same plant with inoculated symptomatic canes, flowered and subsequently produced fruit.

Elderberry cultivars tested in the 2018 study varied in their initial response and subsequent recovery from infection (Table 2). 'Bob Gordon' and 'Wyldewood' canes were most severely affected by the pathogen by 14 DAT, whereas 'Scotia', 'Marge', 'Adams II', and 'Ozark' suffered less dieback. Also, a similar number of canes for each cultivar became infected after inoculation with $H$.

Table 1. Change in vegetative growth of 'Bob Gordon' elderberry canes inoculated with Heterophoma novae-verbascicola or noninoculated on 4 June 2017.

\begin{tabular}{|c|c|c|c|c|c|c|c|c|c|}
\hline \multirow[b]{2}{*}{ Treatment } & \multicolumn{3}{|c|}{ Cane length $(\mathrm{cm})$} & \multicolumn{3}{|c|}{ Leaf no. } & \multicolumn{3}{|c|}{ Leaflet no. } \\
\hline & $14 \mathrm{~d}$ & $30 \mathrm{~d}$ & $60 \mathrm{~d}$ & $14 \mathrm{~d}$ & $30 \mathrm{~d}$ & $60 \mathrm{~d}$ & $14 \mathrm{~d}$ & $30 \mathrm{~d}$ & $\overline{60 \mathrm{~d}}$ \\
\hline Noninoculated & $7.9 \mathrm{a}$ & $19.6 \mathrm{a}$ & $42.0 \mathrm{a}$ & $4.5 \mathrm{a}$ & $11.5 \mathrm{a}$ & $20.0 \mathrm{a}$ & $15 \mathrm{a}$ & $52 \mathrm{a}$ & $118 \mathrm{a}$ \\
\hline
\end{tabular}

${ }^{\mathrm{z}}$ Cane lengths were recorded one day before treatment and 14, 30, and $60 \mathrm{~d}$ after inoculation. Negative values indicate cane dieback, or leaf and leaflet mortality following inoculation. Each value represents the mean of eight replications of each treatment. Mean separation by a pooled test when variances were equal or by the Satterthwaite test when variances were unequal. Means followed by different letters in columns are significantly different $(P \leq 0.05)$. 
Table 2. Change in vegetative growth of elderberry plants inoculated with Heterophoma novae-verbascicola or noninoculated on 14 May $2018 .{ }^{2}$

\begin{tabular}{|c|c|c|c|c|c|c|c|c|c|c|}
\hline \multirow[b]{2}{*}{ Cultivar } & \multirow{2}{*}{$\begin{array}{l}\text { Inoculation } \\
\text { treatment }^{\mathrm{y}}\end{array}$} & \multicolumn{3}{|c|}{ Cane length $(\mathrm{cm})$} & \multicolumn{3}{|c|}{ Leaf no. } & \multicolumn{3}{|c|}{ Leaflet no. } \\
\hline & & $14 \mathrm{~d}$ & $30 \mathrm{~d}$ & $60 \mathrm{~d}$ & $14 \mathrm{~d}$ & $30 \mathrm{~d}$ & $60 \mathrm{~d}$ & $14 \mathrm{~d}$ & $30 \mathrm{~d}$ & $60 d$ \\
\hline Scotia & - & $9.9 \mathrm{a}$ & $23.5 \mathrm{a}$ & $50.1 \mathrm{~b}$ & $4.0 \mathrm{bc}$ & $7.8 \mathrm{bc}$ & $21.0 \mathrm{c}$ & $24 \mathrm{~b}$ & $51 \mathrm{~d}$ & $125 \mathrm{~d}$ \\
\hline Marge & - & $9.0 \mathrm{~b}$ & $21.3 \mathrm{~b}$ & $67.6 \mathrm{a}$ & $5.8 \mathrm{a}$ & $12.8 \mathrm{a}$ & $28.8 \mathrm{a}$ & $35 \mathrm{a}$ & $90 \mathrm{a}$ & $194 \mathrm{a}$ \\
\hline Adams II & - & $8.8 \mathrm{ab}$ & $18.3 \mathrm{c}$ & $46.5 \mathrm{c}$ & $4.4 \mathrm{~b}$ & $8.3 \mathrm{bc}$ & $18.4 \mathrm{~d}$ & $26 \mathrm{~b}$ & $64 \mathrm{bc}$ & $120 \mathrm{e}$ \\
\hline Ozark & - & $7.5 \mathrm{~b}$ & $15.9 \mathrm{~d}$ & $38.6 \mathrm{e}$ & $3.0 \mathrm{c}$ & $7.3 \mathrm{c}$ & $16.3 \mathrm{fg}$ & $18 \mathrm{c}$ & $60 \mathrm{c}$ & $122 \mathrm{e}$ \\
\hline York & - & $7.3 \mathrm{~b}$ & $15.1 \mathrm{~d}$ & $41.5 \mathrm{~d}$ & $4.3 \mathrm{bc}$ & $8.0 \mathrm{bc}$ & $22.9 \mathrm{~b}$ & $31 \mathrm{a}$ & $45 \mathrm{e}$ & $129 \mathrm{c}$ \\
\hline Bob Gordon & - & $7.3 \mathrm{~b}$ & $15.4 \mathrm{~d}$ & $37.1 \mathrm{e}$ & $4.3 \mathrm{bc}$ & $8.0 \mathrm{bc}$ & $23.7 \mathrm{~b}$ & $26 \mathrm{~b}$ & $43 \mathrm{e}$ & $138 \mathrm{~b}$ \\
\hline Wyldewood & - & $7.2 \mathrm{~b}$ & $16.9 \mathrm{~cd}$ & $37.8 \mathrm{e}$ & $3.8 \mathrm{bc}$ & $8.8 \mathrm{~b}$ & $16.8 \mathrm{f}$ & $26 \mathrm{~b}$ & $67 \mathrm{~b}$ & $131 \mathrm{c}$ \\
\hline Scotia & + & $-1.5 \mathrm{c}$ & $2.5 \mathrm{ef}$ & $20.5 \mathrm{~h}$ & $-2.0 \mathrm{~d}$ & $2.0 \mathrm{def}$ & $17.0 \mathrm{e}$ & $-12 \mathrm{~d}$ & $6 \mathrm{hi}$ & $89 \mathrm{~g}$ \\
\hline Marge & + & $-2.9 \mathrm{c}$ & $4.2 \mathrm{e}$ & $51.8 \mathrm{~b}$ & $-2.0 \mathrm{~d}$ & $2.8 \mathrm{de}$ & $18.3 \mathrm{~d}$ & $-10 \mathrm{~d}$ & $16 \mathrm{f}$ & $106 \mathrm{f}$ \\
\hline Adams II & + & $-2.5 \mathrm{c}$ & $0.4 \mathrm{f}$ & $25.3 \mathrm{~g}$ & $-2.0 \mathrm{~d}$ & $0.8 \mathrm{f}$ & $11.0 \mathrm{i}$ & $-11 \mathrm{~d}$ & $5 \mathrm{i}$ & $67 \mathrm{j}$ \\
\hline Ozark & + & $-2.6 \mathrm{c}$ & $0.9 \mathrm{f}$ & $20.3 \mathrm{~h}$ & $-2.0 \mathrm{~d}$ & $2.0 \mathrm{def}$ & $11.5 \mathrm{i}$ & $-11 \mathrm{~d}$ & $11 \mathrm{gh}$ & $72 \mathrm{i}$ \\
\hline York & + & $-5.7 \mathrm{de}$ & $1.5 \mathrm{f}$ & $27.2 \mathrm{f}$ & -3.5 ef & $1.5 \mathrm{ef}$ & $10.3 \mathrm{i}$ & $-19 \mathrm{e}$ & 8 hi & $67 \mathrm{j}$ \\
\hline Bob Gordon & + & $-7.3 \mathrm{e}$ & $3.9 \mathrm{e}$ & $21.1 \mathrm{~h}$ & $-4.5 \mathrm{f}$ & $2.8 \mathrm{de}$ & $15.3 \mathrm{gh}$ & $-26 \mathrm{f}$ & $14 \mathrm{fg}$ & $80 \mathrm{~h}$ \\
\hline Wyldewood & + & $-7.2 \mathrm{e}$ & $3.5 \mathrm{e}$ & $23.7 \mathrm{~g}$ & $-2.3 \mathrm{de}$ & $3.0 \mathrm{~d}$ & $14.8 \mathrm{~h}$ & $-16 \mathrm{e}$ & $16 \mathrm{f}$ & $85 \mathrm{~g}$ \\
\hline
\end{tabular}

${ }^{\mathrm{z}}$ Cane lengths were recorded the day before treatment and 14, 30, and $60 \mathrm{~d}$ after inoculation. Negative values indicate cane dieback, or leaf and leaflet mortality following inoculation. Each value represents the mean of eight replications of each treatment, except for Scotia. Only two inoculated Scotia plants exhibited cane dieback and foliar necrosis. Mean separation by a pooled test when variances were equal or by the Satterthwaite test when variances were unequal. Means followed by different letters in columns are significantly different $(P \leq 0.05)$.

${ }^{\mathrm{y}}$ Minus and plus symbols indicate mock-inoculation and inoculation with the putative pathogen, respectively.

novae-verbascicola, with the exception of 'Scotia'. In the first experiment conducted 2017, none of the inoculated 'Scotia' canes expressed symptoms of fungal infection and only one inoculated cane had stem and foliar necrosis in the next experiment. In 2018, $H$. novae-verbascicola was re-isolated from one cane on each of two 'Scotia' plants. The reason for the higher number of infected 'Scotia' canes in the latter two experiments may be attributed to the 10 -fold or greater increase in conidia used as inoculum. Other differences in cellular or tissue anatomy among American elderberry that may account for decreased susceptibility of 'Scotia' canes are unknown.

'Marge' had the greatest cane growth among all inoculated cultivars by 60 DAT, while 'Scotia', 'Ozark', and 'Bob Gordon' had the least cane growth (Table 2). When cane dieback occurred, growth from proximal axillary buds occurred. Also, by $60 \mathrm{DAT}$, all inoculated canes with dieback had a $29 \%$ to $48 \%$ reduction in leaflets compared with controls, with 'Scotia' having the smallest percent loss. Such reductions in leaf loss likely limit the photosynthetic activity and carbon assimilation of elderberry plants when $H$. novae-verbascicola infection occurs.

This study also revealed differences in the growth habit of noninoculated elderberry cultivars. The European cultivar, Marge, had more vigorous growth (i.e., cane length and number of leaflets) than any of the American cultivars (Table 2). Among the American elderberry cultivars with the least cane growth at 60 DAT ('Ozark', 'Bob Gordon', and 'Wyldewood'), 'Ozark' produced the fewest leaflets per cane. The open growth habit of 'Ozark', allowing more air circulation within plants, may have implications in infection rates of other pathogens commonly associated with elderberry, such as those pathogens causing leaf spots and elderberry rust. Although fruit yield data were not recorded in this study, the leaflet:fruit ratio of 'Ozark' plants may also contribute to the higher fruit yield of this cultivar compared with 'York', 'Bob Gordon', and 'Wyldewood' as reported by others (Thomas et al., 2015a).

The number of leaflets per leaf also varied among cultivars. While all cultivars had oddpinnately compound leaves, 'York' and 'Wyldewood' plants had leaves with as many as 11 leaflets by 60 DAT (data not shown). 'Bob Gordon', 'Adams II', 'Ozark', and 'Marge' produced up to 9 leaflets per leaf, whereas 'Scotia' had as many as 7 leaflets per leaf by 60 DAT. Others reported that American elderberry plants have 5 to 11 leaflets, usually averaging 7, whereas European elderberry leaflets range from 3 to 9 leaflets (Atkinson and Atkinson, 2002; Charlebois et al., 2010; Lawrence, 1951). In our study, all cultivars from both elderberry subspecies produced some leaves with as few as 3 leaflets, which mostly occurred as secondary growth from axillary buds of main canes of both inoculated and noninoculated control plants.

In conclusion, a fungal strain, tentatively identified as Heterophoma novae-verbascicola, was causally associated with elderberry cane dieback and leaf mortality in a commercial planting. Canes of six American elderberry cultivars and a European cultivar (Marge) were susceptible to the fungus and had visible symptoms of infection after inoculation. When cane dieback occurred on infected canes, fruit production on the affected tissue was eliminated. However, Sambucus nigra ssp. canadensis 'Scotia' plants were apparently less susceptible to Heterophoma sp. infection after inoculation. This result suggests that 'Scotia' may be useful in developing new elderberry cultivars with improved resistance to $H$. novae-verbascicola infection using conventional breeding techniques.

\section{Literature Cited}

Altschul, S.F., W. Gish, W. Miller, E.W. Myers, and D.J. Lipman. 1990. Basic local alignment search tool. J. Mol. Biol. 215:403-410.
Atkinson, M.D. and E. Atkinson. 2002. Sambucus nigra L. J. Ecol. 90:895-923.

Baker, J.B., J.F. Hancock, and D.C. Ramsdell. 1995. Screening highbush blueberry cultivars for resistance to Phomopsis canker. HortScience 30:586-588.

Bertetti, D., G. Ortu, M.L. Gullino, and A. Garibaldi. 2016. Contamination of moth mullein (Verbascum blattaria L.) seeds by Phoma novaeerbascicola. J. Plant Pathol. 98:361-363.

Byers, P.L. and A.L. Thomas. 2011. 'Bob Gordon' elderberry. J. Amer. Pomological Soc. 65:5255.

Byers, P.L., A.L. Thomas, and M. Millican. 2010. 'Wyldewood' elderberry. HortScience 45:312313.

Charlebois, D., P.L. Byers, C.E. Finn, and A.L. Thomas. 2010. Elderberry: Botany, horticulture, potential. Hort. Rev. 37:213-280.

Chen, Q., J.R. Jiang, G.Z. Zhang, L. Cai, and P.W. Crous. 2017. Resolving the Phoma enigma. Stud. Mycol. 82:137-217.

Cottrill, D.J., D.T. Earlywine, and G.L. Miller. 2016. Assessment of nitrogen source, sulfur, and fall fungicide applications on the management of spring dead spot of Bermudagrass. Plant Dis. 100:473-482.

Finn, C.E., A.L. Thomas, P.L. Byers, and S. Serçe. 2008. Evaluation of American (Sambucus canadensis) and European (S. nigra) elderberry genotypes grown in diverse environments and implications for cultivar development. HortScience 43:1385-1391.

Gardes, M. and T.D. Bruns. 1993. ITS primers with enhanced specificity for basidiomycetesApplications to the identification of mycorrhizae and rusts. Mol. Ecol. 2:113-118.

Garibaldi, A., D. Bertetti, A. Poli, and M.L. Gullino. 2013. A leaf spot caused by Phoma novae-verbascicola on black mullein (Verbascum nigrum L.) in Italy. Plant Dis. 97:1660.

Godsey, L. 2012. Elderberry financial decision support tool. University of Missouri Center for Agroforestry. 10 Jan. 2019. <http://www.center foragroforestry.org/profit/elderberryfinance.php>.

Henrion, B., F. LeTacon, and F. Martin. 1992. Rapid identification of genetic variation in ectomycorrhizal fungi by amplification of ribosomal RNA genes. New Phytol. 122:289-298.

Lawrence, G.H.M. 1951. Taxonomy of vascular plants. Macmillan, New York, NY.

Littell, R.C., P.R. Henry, and C.B. Ammerman. 1998. Statistical analysis of repeated measures 
data using SAS procedures. J. Anim. Sci. 76:1216-1231.

Mohebalian, P.M., M.M. Cernusca, and F.X. Aguilar. 2012. Discovering niche markets for elderberry juice in the United States. HortTechnology 22:556-566.

Parker, P.E. and D.C. Ramsdell. 1977. Epidemiology and chemical control of Phomopsis canker of highbush blueberry. Phytopathology 67:14811484.

Pirone, P.P., B.O. Dodge, and H.W. Rickett. 1978. Diseases and pests of ornamental plants. Wiley, New York.

Reynolds, H.T. and H.A. Barton. 2014. Comparison of the white-nose syndrome agent Pseudogymnoascus destructans to cave-dwelling relatives suggests reduced saprotrophic enzyme activity. 10
Jan. 2019. <https://journals.plos.org/plosone/ article?id=10.1371/journal.pone.0086437>.

Thomas, A.L., P.L. Byers, J.D. Avery, Jr., M. Kaps, and S. Gu. 2015a. Horticultural performance of eight American elderberry genotypes at three Missouri locations. Acta Hort. 1061:237-244.

Thomas, A.L., P.L. Byers, J.D. Avery, Jr., M. Kaps, S. Gu, H.Y. Johnson, and M. Millican. 2015b. 'Marge': A European elderberry for North American producers. Acta Hort. 1061:191199.

Walter, H., L. Muggia, M. Fritscher, A. Holler, D. Horvat, H. Guttenberger, and U.K. Simon. 2016. Multiple taxa in the Phoma-complex associate with black elder (Sambucus nigra L.). Fungal Biol. 120:43-50.
Warmund, M., M. Kwasniewski, J. Elmore, A. Thomas, and K. Adhikari. 2016. Sensory attributes of juice from North American-grown elderberry cultivars. HortScience 51:15611565.

Warmund, M., J. Mihail, and K. Hensel. 2019. Puccinia sambuci infection of American elderberry plants. HortScience 54:1-5.

Weingartner, D.P. and E.J. Klos. 1975. Etiology and symptomatology of canker and dieback diseases of highbush blueberries caused by Godronia (Fussicoccum) cassandrae and Diaporthe (Phomopsis) vaccinia. Phytopathology 65:105-110.

Zomlefer, W.B. 1994. Guide to flowering plant families. Univ. North Carolina Press, Chapel Hill, NC. 